УДК 56.074.2 (26)

\title{
О БИОГЕОГРАФИЧЕСКИХ РЕКОНСТРУКЦИЯХ МОРСКИХ ФАУН ГЕОЛОГИЧЕСКОГО ПРОШЛОГО
}

\author{
Бяков А. С. ${ }^{1,2}$ \\ ${ }^{\text {I} Ф Г Б У Н ~ С е в е р о-В о с т о ч н ы и ̆ ~ к о м п л е к с н ы и ̆ ~ н а у ч н о-и с с л е д о в а т е л ь с к и и ̆ ~ и н с т и т у т ~}$ \\ им. Н. А. Шило ДВО РАН, г. Магадан \\ ${ }^{2}$ Северо-Восточный государственный университет, г. Магадан \\ E-mail: abiakov@mail.ru
}

\begin{abstract}
Рассмотрены некоторые вопросы биогеографических реконструкций морских фаун геологического прошлого. Обсуждается природа биогеографических границ и рассматриваются критерии выделения и ранг устанавливаемых биохорий, в частности, применимость различных индексов биогеографического сходства. Сделан вывод, что лишь использование всего комплекса методов палеобиогеографических исследований позволяет наиболее достоверно реконструировать особенности географической дифференциации древних организмов. Такие реконструкции необходимо проводить для возможно более дробных временных интервалов на видовом уровне и на основе интеграции данных по всем группам фауны.
\end{abstract}

Ключевые слова: палеобиогеография, биохории, природа, ранг и критерии выделения биохорий.

DOI: $10.34078 / 1814-0998-2021-3-34-43$

\section{ВВЕДЕНИЕ}

Биогеографическое районирование морских бассейнов геологического прошлого является одной из наиболее важных и сложных задач, стоящих перед палеонтологами. В последнее время опубликован ряд работ, рассматривающих различные стороны этой проблемы - от решения номенклатурных вопросов биогеографии до практического использования результатов палеобиогеографических реконструкций в целях проверки геодинамических моделей (Захаров и др., 1996, 2003; Богословская, 1997; Westermann, 2000; Shen et al., 2003; Захаров, 2003, 2005; и др.).

Различным вопросам палеобиогеографического районирования посвящено множество работ (Устрицкий, 1970, 1986; Дагис, 1970; Крымгольц, Эйнор, 1972; Макридин, 1973; Собецкий, 1978; Виленкин, Шилейко, 1979; Скарлато, 1981; Песенко, 1982; Морская..., 1982; Макридин, Мейен, 1988; Кафанов, 1991, 2005; Грунт и др., 1994; Грунт, 1995; Грунт, Розанов, 1995; Сесса, Westermann, 2003; Захаров и др., 2003; Миронов, 2004; Гладенков, 2005; Кафанов, 2005; Захаров, 2005; Никитенко, 2008; и др.), широко обсуждаемых в последнее время. Это касается как общих принципов установления, описания, номенклату-

(C) Бяков А. С., 2021 ры биохорий различного ранга древних бассейнов, так и биогеографических исследований по разным группам и разным временным интервалам, в том числе современным организмам. Тем не менее существует множество проблем, среди которых прежде всего назовем следующие: какова номенклатура и иерархия выделяемых биохорий; каковы критерии установления биохорий; должны ли принципы выделения биохорий прошлого соответствовать используемым для выделения современных биогеографических единиц; насколько обосновано установление биохорий наиболее низкого ранга на ископаемом материале; какова природа биогеографических границ.

\section{КРИТЕРИИ ВЫДЕЛЕНИЯ И РАНГ УСТАНАВЛИВАЕМЫХ БИОХОРИЙ}

Среди специалистов нет единого мнения по поводу критериев выделения и ранга устанавливаемых биохорий. Так, А. С. Дагис (1970) отмечает, что эти критерии устанавливаются эмпирически. Некоторые авторы используют простое сравнение списков определений таксонов (Попеко, 1996; Брагин, 2005), другие применяют кластерный анализ (Shi, 1993; Shi, Archbold, 1996; Кафанов, 2005; Кафанов, Огасавара, 2006; Никитенко, 2008) и компьютерные программы (Наймарк и др., 1999; Елкин и др., 2007). 
Ряд исследователей считают, что использование родовых категорий для палеобиогеографического анализа якобы более корректно, поскольку диагностика родов, на их взгляд, менее субъективна, чем видов (Устрицкий, 1970; Захаров, Шурыгин, 1978; Никитенко, 2008; и др.). По О. Н. Зезиной (Морская..., 1982), использование родовых таксонов предусматривает исторический подход к районированию морских бассейнов.

В то же время многие специалисты по современной фауне, в частности, О. Н. Зезина (1976, 1985), отмечают, что биогеографический анализ морской фауны на видовом уровне позволяет связать границы ареалов видов с границами водных масс, что открывает возможность палеогидрологических реконструкций древних бассейнов. Кроме того, в некоторых случаях построения, проведенные на уровне родов, не позволяют выявить биогеографические неоднородности, что отмечается, в частности, для современных брахиопод (Морская..., 1982). Такого же мнения придерживаются Е. А. Елкин и др. (1985) и Т. А. Грунт (1995). Интересно отметить, что, как пишет А. И. Кафанов (1991. С. 88), «нередко результаты биогеографического районирования, полученные на основе изучения таксонов разного ранга, обнаруживают значительные различия».

В последнее время палеобиогеографическое районирование с использованием таксонов видового ранга начинает все больше использоваться и для древних организмов (Попов, 1994; Амитров, 1996; Басов, 1999; Князев, Прокопьев, 1999; Віаkov, Shi, 2010; и др.). Пример такого районирования, наглядно иллюстрирующий возможности использования видовых таксонов для детальной биогеографии, приведен на рисунке.

Некоторые специалисты считают, что из-за неполноты палеонтологической летописи ранг выделяемых на ископаемом материале биохорий должен быть выше, чем современных. Так, В. И. Устрицкий (1970) полагает, что для бореальных бассейнов позднего палеозоя выделение более дробных единиц, чем провинция, практически невозможно. М. С. Месежников (1974) считает, что принципы выделения современных и древних биохорий существенно различны, поскольку даже для части века палеозоогеографические провинции представляют собой некоторый усредненный результат некогда существовавших зоохорий.

В. Н. Сакс и др. (1971), О. В. Юферев (1973) и Н. И. Шульгина (1974) в качестве наиболее крупной единицы палеогеографического районирования выделяют пояс, однако большинство исследователей, в первую очередь изучающих современные фауны, считают в настоящее время таковой надобласть (см. Захаров, 2005).
В. П. Макридин (1973), В. А. Собецкий (1978) и Н. И. Курушин (1995) предлагают в качестве категории наиболее низкого ранга считать район, О. А. Скарлато (1981), Я. И. Старобогатов (Морская..., 1982), Т. А. Грунт и А. Ю. Розанов (1995)округ. Н. В. Сенников (1996) выделяет еще более дробные единицы - участки и местонахождения. На состоявшемся недавно международном совещании объединением «Друзья палеогеографии» (Захаров, 2005) в качестве элементарной палеобиогеографической единицы рекомендована подпровинция, что ранее предлагал Г. Вестерманн (Westermann, 2000).

Ряд исследователей считают возможным выделение самостоятельных биохорий даже в случае резкого таксономического обеднения фаун (Устрицкий, 1970) или, наоборот, полного отсутствия эндемичных таксонов.

Г. Я. Крымгольц, О. Л. Эйнор (1972), Н. И. Шульгина (1974) и др. полагают, что ранг выделяемых биохорий связан с рангом таксонов, используемых при биогеографическом анализе.

Многие специалисты считают, что наиболее крупные биохории (области, подобласти) должны характеризоваться эндемичными таксонами высокого ранга (семействами и подсемействами), тогда как провинции - родами и подродами (Устрицкий, 1970; Макридин, 1973; Шульгина, 1974; Макридин, Мейен, 1988; Богословская, 1997). Но такое утверждение принимается далеко не всеми специалистами, особенно исследующими современную фауну. Так, например, А. И. Кафанов (1991) отмечает, что провинции изученной им Северотихоокеанской области не содержат эндемичных родов двустворчатых моллюсков, а общая доля эндемичных родов составляет немногим более $5 \%$. То же ранее отмечал и О. Г. Кусакин (1979) для современных равноногих раков. В конечном итоге А. И. Кафанов (1991. С. 154) приходит к выводу, что «при биогеографическом анализе нет оснований придавать приоритетное значение рангу и степени эндемизма..., хотя показатели эндемизма ... имеют важное дополнительное значение». О. Н. Зезина (Морская..., 1982) считает, что наличие или отсутствие родов-эндемиков в составе тех или иных географических элементов фауны не связано с большей или меньшей степенью биогеографической обособленности, а служит лишь оценкой продолжительности изолированности фаун. Г. Вестерманн (Westermann, 2000) полагает, что биохории должны основываться на возможно большем количестве высших таксонов одного крупного биома и определяться по общему эндемизму его биоты. При этом важно устанавливать длительно существовавшие автохтонные таксоны и их филогенетические взаимоотношения. 

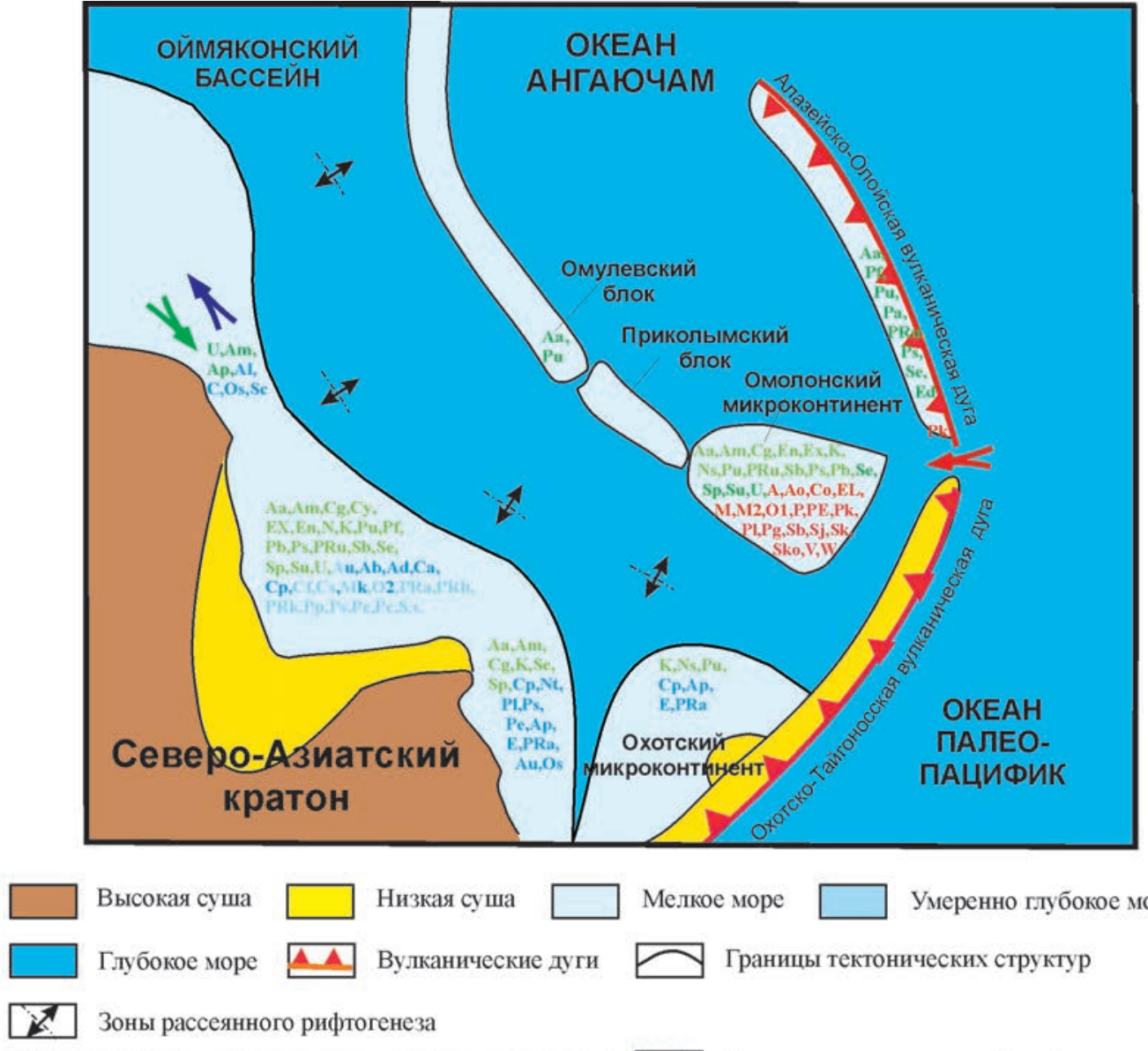

Высокая суша

Низкая суша

Мелкое море

Умеренно глубокое море

Глубокое море

Вулканические дуги

Границы тектонических структур

Зоны рассеянного рифтогенеза

Предполагаемые миграции двустворчатых моллюсков:

Из североамериканских бассейнов

$\gg$ Из других бассейнов Тетиса $\longleftrightarrow$ Из западнобореальных бассейнов

$\longrightarrow$ Миграции колымо-омолонских и верхояно-охотских двустворок в другие бассейны

Буквами обозначены виды двустворок:

Общие между провинщиями: Aa - Aphanaia andrianovi, Am - Astartella multicostata, Cg - Costatoaphanaia ganelini, En -Edmondia ex gr. nebrascensis, EX - Exochorhynchus similis, $\mathrm{K}$ - Kolymopecten kolymaensis, Ns - Nuculopsis sp.,

$\mathrm{Pf}-$ Phestia ex gr. flexuosa, Pu - Phestia undosa, Pa - Parallelodon striatus, $\mathrm{Pb}$ - Pyramus bonus, $\mathrm{Ps}$ - Pyramus symmetricus, PRu - Praekolymia urbajtisae, Sb - Solemya biarmica, Se - Streblopteria englehardti, Sp - Streblopteria pusilla, Su - Streblopteria ex gr, krasnoufimskensis, U - Undopecten keyserlingi

Характерные только для Колымо-Омолонской провинции: А - "Aviculopecten" sp., A0 - Astartella ex gr. omolonica, Co-Cypricardinia orientalis, EL-Elimata? sp. indet., G-Grammysiopsis cf. omolonicus, M-Myalina? sp. indet., M2-Mionia sp. 2, 01 - Oriocrassatella sp. 1, P-Pseudomonotis? sp., PE - "Permophorus" sp., Pk - Palaeolima ex gr. kasanensis, PI - Plagiostoma ? sp. indet., Pg - Praeundulomya gijigensis, $\mathrm{Sb}$ - Streblopteria cf. bella, Sj - Schizodus aff. jakovlevi, Sk - Streblopteria ex gr. krasnoufimskensis, Sko - Solenomorpha kogimica, V-Vacunella praecurvata, W - Wilkingia aff. abramovi

Характерные только для Верхояно-Охотской провинции: $\mathrm{Al}$-Aphanaia budnikovi, Al-Acanthopecten licharewi, 41 - Aphanaia pogorevitschi, Au - “Aviculopecten” uralicus, C - Cigarella sp. nov., Ca - Costatoaphanaia aenigma, - Costatoaphanaia formosa, Cs - Cypricardinia sp. nov., Cp - Costatoaphanaia popowi, E - Euchondria sp.,

11 -Myonia kutygini, M11-Myonia sp. 1, N1-Nuculopsis trivialis, Os - Obliquipecten sericeus, 02 -Oriocrassatella sp. 2,

'a - Praekolymia archboldi, Pe - Prothyris cilindricus, Ppe - Permophorus angustus, Pel - Praeundulomya elongata,

PI - Phestia lunulata, Psi - Phestia sinuata, Pp - Praeundulomya cf. petschorica, Ps - Permophorus sp., Ra - Praekolymia? alitis, Prb - Praekolymia barajensis, S\& - Solemya solikamica, $\mathrm{Sp}_{\mathrm{P}}$-Schizodus subcordatus

Рисунок. Биогеографическое распределение двустворок в середине кунгурского века на Северо-Востоке России (по Бяков, 2010)

Figure. Biogeographic distribution of Middle Kungurian bivalves in Northeast Russia (after Biakov, 2010)

По Э. Г. Кауфману (Kauffman, 1973), подпровинции должны содержать 10-25 \% эндемичных видов, провинции - 25-50 \%, а области 50-75 \%. Д. Хеджпет (Hedgpeth, 1957. Цит. по: Талент, 1985) считает, что провинция должна ха- рактеризоваться не менее чем 50 \% эндемиков. По О. А. Скарлато (1981), различные биохории должны содержать не более 33 \% общих видов. О. Н. Зезина (1976) определила, что процент эндемичных родов современных брахиопод в уста- 
новленных ею «поясах климатической зональности» составляет от 12 до 31.

По мнению ряда исследователей (Грунт и др., 1994; Грунт, Розанов, 1995; и др.) большое значение имеет «общий облик» биоты, или «лицо фауны», которое могут определять таксоны разного таксономического уровня из совершенно разных групп биоты. Большое значение придается здесь, прежде всего, степени ее эндемизма (Cесca, Westermann, 2003), при определении которой следует учитывать, в том числе, площадь ареалов того или иного эндемичного таксона (Семенов, 1975).

В последнее время также уделяется большое внимание геоисторическому подходу при выделении биохорий (Грунт и др., 1994; Грунт, Розанов, 1995; Захаров и др., 2003; Захаров, 2005).

Многие специалисты, прежде всего изучающие современные моллюски, считают что при выделении биохорий следует обращать особое внимание на центры видообразования (Скарлато, 1981; Морская..., 1982; Грунт, Розанов, 1995; Гладенков, 2005), т. е. самостоятельная провинция должна иметь собственный центр видообразования. Некоторые исследователи при районировании на видовом уровне придают особое значение так называемым видам-детерминантам (Морская..., 1982).

\section{ИНДЕКСЫ БИОГЕОГРАФИЧЕСКОГО СХОДСТВА КАК КРИТЕРИИ ВЫДЕЛЕНИЯ БИОХОРИЙ}

Для более объективного определения биохорий многие исследователи используют различные индексы (или коэффициенты) биогеографического сходства (Жаккара, Чекановского - Сьеренсена, Симпсона, Престона, Ламберта, Лонга и др.). Обзор и сравнение этих индексов проведены Ю. А. Песенко (1982).

А. И. Кафанов (1991), а также Е. Б. Наймарк и А. В. Марков (1998), Р. В. Горюнова и др. (2004) наиболее информативным считают индекс Чекановского - Сьеренсена ( $\left.\mathbf{I}_{c s}\right)$ :

$\mathbf{I}_{c s}=\mathbf{2} \mathbf{c} /\left(\mathbf{s}_{1}+\mathbf{s}_{2}\right)$, где $\mathbf{c}-$ число общих видов; $\mathbf{s}_{1}$ и $\mathbf{s}_{2}$ - количество таксонов в каждой из двух сравниваемых фаун.

Весьма информативным является также индекс Жаккара $\left(\mathbf{I}_{j}\right)$ :

$\mathbf{I}_{j}=\mathbf{c} /\left(\mathbf{s}_{1}+\mathbf{s}_{2}\right)-\mathbf{c}$, где $\mathbf{c}-$ количество общих видов; $\mathbf{s}_{1}$ и $\mathbf{s}_{\mathbf{2}}-$ число таксонов в каждой из двух сравниваемых фаун. По П. Жаккару (Jaccard, 1912), если степень сходства сравниваемых биохорий, вычисленных по предложенной формуле, составляет менее 0.50 , эти биохории рассматриваются как различные.

Индекс Жаккара связан с индексом Чекановского - Сьеренсена соотношением $\mathbf{I}_{j}=\mathbf{I}_{c s} / \mathbf{2}-\mathbf{I}_{c s}$ (Кафанов, 1991).
Широко используется также индекс Престона $\left(\mathbf{I}_{p}\right): \mathbf{I}_{p 1}=\mathbf{s}_{1} /\left(\mathbf{s}_{1}+\mathbf{s}_{2}\right)-\mathbf{c}, \mathbf{I}_{p 2}=\mathbf{s}_{2} /\left(\mathbf{s}_{1}+\mathbf{s}_{2}\right)-\mathbf{c}$, где $\mathbf{I}_{p 1}$ и $\mathbf{I}_{p 2}-$ значения индексов Престона сравниваемых биохорий. Согласно Ф. Престону (Preston, 1962), если коэффициент различия между биохориями составляет более 0.27 , то они являются разными. Для вычисления этого коэффициента удобно пользоваться специальной таблицей, приведенной Я. И. Старобогатовым (1970. С. 10).

Многие специалисты для разграничения отдельных биохорий указывают различные значения упомянутых индексов. Так, О. А. Скарлато (1981) при изучении современных двустворчатых моллюсков умеренных широт западной части Тихого океана путем эмпирических вычислений установил, что для различий провинциального ранга значение коэффициента Жаккара должно составлять менее 0.50 , Престона - более 0.38 .

Однако В. Н. Семенов (Морская..., 1982), исследуя разные группы современных морских беспозвоночных шельфа Южной Америки, установил собственные эмпирические значения показателей различия (индексов Престона и Жаккара), характеризующие подразделения разного биогеографического ранга. Так, установленные им значения коэффициентов, характеризующие разные провинции, находятся в пределах 0.420.58 (индекс Жаккара) и 0.33-0.41 (индекс Престона).

С. В. Попов, изучавший палеогеновые двустворчатые моллюски Западной Евразии (1994), пришел к выводу, что в ряде случаев весьма близкие, по его мнению, фауны обнаруживают значение индекса Престона около 0.5 , в связи с чем он также использует свои показатели различия биохорий по этому индексу, которые, в частности, для разных провинций составляют 0.70-0.86 на уровне видов и 0.50-0.69- на уровне родов. Следует, однако, отметить, что изученные им фауны обитали в достаточно изолированном морском бассейне, чем и могут объясняться такие значительные расхождения предлагаемых С. В. Поповым значений от первоначально установленных Ф. Престоном.

Б. Я. Виленкин и А. А. Шилейко (1979), справедливо полагая, что степень эндемизма фаун сравниваемых регионов во многом зависит от общего количества видов, предложили способ оценки уровня эндемизма фауны с использованием уравнения регрессии. А. И. Кафанов (2005) отмечает, что все индексы общности зависят как от длины сравниваемых списков видов, так и от относительного числа общих видов в них. Вместе с тем он считает «количественный анализ видового богатства основным операционным методом биогеографии» (Кафанов, 1991. С. 81). 
Как отмечают В. П. Макридин и С. В. Мейен (1988. С. 19), «решение вопроса о ранге биохорий не может основываться на одном ... отдельно взятом методе», и статистический метод, таким образом, может служить лишь как дополнительный инструмент для оценки ранга биохорий. Такого же мнения придерживается и В. И. Устрицкий (1970).

Итак, использование различных коэффициентов для определения биогеографического сходства, как отмечают многие авторы, далеко не всегда эффективно даже для современных однотипных морских бассейнов. Тем более этот факт очевиден, если рассматривать древние бассейны. Здесь даже для мелководных фаций систематический состав сообществ определяется главным образом спецификой бассейна и условиями существования фауны.

Последнее отчетливо видно на примере Тасканского бассейна, расположенного в пределах Омулевского блока и изученного нами (Бяков и др., 2006). Рассматриваемый бассейн, несмотря на его относительную мелководность (глубины осадконакопления здесь, очевидно, не превышали 50-100 м), характеризуется крайне бедным составом фауны. Среди нее резко доминируют иноцерамоподобные двустворки, составляющие до 95-99 \% сообществ и представленные всего лишь несколькими видами (например, в зоне Inoceramiformis здесь известны только 3 вида двустворок), тогда как одновозрастные сообщества Омолонского бассейна характеризуются в несколько раз более богатым таксономическим составом (24 вида). Вычисленный индекс Жаккара составляет 0.11 , формально указывая на различия провинциального ранга. В то же время близость этих фаун очевидна - все 3 вида двустворок, обитавших в Тасканском бассейне, обнаружены и в Омолонском. Кроме того, только в этих бассейнах встречен вид Kolymia taskanica Biakov, не известный более нигде.

Ранее автором (Бяков, 2010) была рассмотрена биогеографическая дифференциация двустворчатых моллюсков Колымо-Омолонской и Верхояно-Охотской провинций Восточнобореальной области в течение перми для 13 временHblX срезов, каждый из которых по продолжительности отвечает, как правило, той или иной зоне. Использование индексов сходства Жаккара и Престона показало, что фауны двустворок этих двух провинций значительно отличались между собой на протяжении всей перми, кроме самого ее начала (ассельского века), и могут рассматриваться как две разные биохории провинциального ранга. Эти различия в целом последовательно увеличивались на протяжении перми, о чем говорят значения упомянутых индексов. Так, индекс Жаккара составлял в среднем 0.30, что зна- чительно ниже минимального показателя (0.42), обычно принимаемого для разграничения биогеографических провинций.

\section{ПРИРОДА БИОГЕОГРАФИЧЕСКИХ ГРАНИЦ}

В современной литературе также широко обсуждается сущность биогеографических границ, наиболее полный обзор принципов выделения и природы которых дан А. Н. Мироновым (2004) и А. И. Кафановым (2005).

В. Н. Семенов (Морская..., 1982), проводивший анализ современной фауны морских беспозвоночных шельфа Южной Америки, пришел к выводу, что границы биохорий хорошо совпадают с климатическими границами среды. О. Н. Зезина (1985), как говорилось ранее, отмечает, что биогеографический анализ морской фауны на видовом уровне позволяет связать границы ареалов видов с границами водных масс.

Особенности биогеографического распределения организмов в немалой степени контролируются глубиной бассейна. Для глубоководных сообществ, прежде всего для современных фаун (Кафанов, 1991; и др.), обычно используется свое биогеографическое районирование, что некоторые специалисты рекомендуют и для ископаемых организмов (Грунт, Розанов, 1995), хотя Д. Л. Кальо (1981) считает, что такое разделение необходимо только на уровне района, тогда как на уровне провинций и выше должно обобщаться. Последнее утверждение достаточно хорошо подтверждается и нашими материалами, которые показывают, что в целом состав глубоководных сообществ сходен в разных бассейнах.

\section{ЗАКЛЮЧЕНИЕ}

Из изложенного следует, что лишь использование всего комплекса методов палеобиогеографических исследований с учетом специфики, присущей ископаемым сообществам, в том числе их исторического развития, позволяет наиболее достоверно реконструировать особенности географической дифференциации древних организмов. Такие реконструкции, по нашему мнению, необходимо проводить для возможно более дробных временных интервалов на видовом уровне и на основе интеграции данных по всем группам фауны.

Для пермских морских бассейнов, изучением которых занимается автор статьи, по ряду причин в настоящее время такой всеобъемлющий синтез пока не осуществлен, хотя в самых общих чертах (в частности, без количественного анализа) биогеографические исследования проводились ранее В. И. Устрицким (1970), а также Т. А. Грунт (1995). Кроме того, некоторые специалисты (Шульгина, 1974) считают, что вначале следует проводить районирование по однотипным 
фаунам, после чего полученные данные должны быть суммированы. Поэтому проведение палеобиогеографических реконструкций даже с использованием только одной группы (в частности, двустворок), но на видовом уровне и для века или его части представляется очень важным.

Исследование выполнено при финансовой поддержке РФФИ в рамках научного проекта № 20-0500604.

Автор благодарит рецензентов Ю. Д. Захарова и P. В. Кутыгина за высказанные замечания, способствовавшие улучшению текста статьи.

\section{ЛИТЕРАТУРА}

Амитров О. В. К палеогеографии и климатической зональности раннеолигоценовых морей запада Евразии по брюхоногим моллюскам // Палеонтологический журнал. 1996. № 1. С. 3-12.

Басов И. А. Биогеография планктонных фораминифер Северной Пацифики в палеогене и эоцене // Стратиграфия. Геол. корреляция. 1999. Т. 7, № 1. С. 86-98.

Богословская М. Ф. Биогеографический анализ средне- и позднекаменноугольных аммоноидей // Палеонтологический журнал. 1997. № 5. С. 27-40.

Брагин Н. Ю. Палеобиогеографическое районирование триасовых акваторий по радиоляриям // Биосфера - экосистема - биота в прошлом Земли: палеобиогеографические аспекты. К 100-летию со дня рождения академика В. В. Меннера / отв. ред. Ю. Б. Гладенков, К. И. Кузнецова. Москва : Наука, 2005. C. $157-177$.

Бяков А. С. Зональная стратиграфия, событийная корреляция, палеобиогеография перми Северо-Востока Азии (по двустворчатым моллюскам). Магадан : СВКНИИ ДВО РАН, 2010. 262 с.

Бяков А. С., Ведерников И. Л., Колесов Е. В. Предварительные результаты изучения пермских отложений юга Омулевского блока (Северо-Восток Азии) // Геология, география и биологическое разнообразие Северо-Востока России : Материалы Дальневосточной региональной конференции, посвященной памяти А. П. Васьковского и в честь его 95-летия. Магадан : СВНЦ ДВО РАН, 2006. С. 71-75.

Виленкин Б. Я., Шилейко А. А. Способ оценки уровня эндемизма фауны // Зоологический журнал. 1979. Т. 58. Вып. 11. С. 1720-1727.

Гладенков Ю. Б. Стратиграфия и актуальные направления палеобиогеографических исследований // Биосфера - экосистема - биота в прошлом Земли: палеобиогеографические аспекты. К 100-летию со дня рождения академика В. В. Меннера / отв. ред. Ю. Б. Гладенков, К. И. Кузнецова. Москва : Наука, 2005. C. $17-45$.

Горюнова Р. В., Наймарк Е. Б., Марков А. В. Эволюция и биогеография палеозойских мшанок: результаты количественного анализа. Москва : ГЕОС, 2004. $182 \mathrm{c}$.

Грунт T. A. Биогеография пермских морских бассейнов // Палеонтологический журн. 1995. № 4. C. 10-24.

Грунт Т. А., Розанов А. Ю. Некоторые вопросы исторической биогеографии // Палеобиогеография, центры происхождения и миграция организмов : тез. докл. 41-й сессии Палеонтол. общества. 1995. C. $18-20$.

Грунт Т. А., Розанов А. Ю., Алексеева Р. Е., Мананков И. Н. Некоторые подходы к проблемам исторической биогеографии морских бассейнов // Экосистемные перестройки и эволюция биосферы. Москва : ПИН РАН, 1994. Вып. 1. С. 205-212.

Дагис А. С. Триасовые брахиоподы. Морфология, система, филогения, стратиграфическое значение и биогеография : автореф. дис. ... д. г.-м. Н. Новосибирск, 1970. $43 \mathrm{c}$.

Елкин Е. А., Талент Дж. А., Грацианова Р. Т. Австрало-Азиатские позднесилурийские - раннекаменноугольные брахиоподы и трилобиты // Геология и геофизика. 1985. № 12. С. 3-7.

Елкин Е. А., Талент Дж. А., Изох Н. Г., Киприянова Т. П., Киприянов А. А., Грацианова Р. Т., Елкина В. Н., Щербаненко T. А. Районирование раннесреднедевонских морей Северной Евразии на основе количественных оценок палеобиогеографических связей между региональными видовыми ассоциациями брахиопод // Верхний палеозой России: стратиграфия и палеогеография : Материалы Всерос. науч. конф. Казань : Казанский гос. ун-т, 2007. С. $102-$ 107.

Захаров B. А. Сравнительный анализ палинспастических и палеобиогеографических реконструкций высокоширотных областей Северного полушария в мезозое // Палеонтология и природопользование : тез. докл. 49-й сессии Палеонтол. общества. СанктПетербург, 2003. С. 93-95.

Захаров В. А. Палеобиогеография, палеогеография и палеогеодинамика // Биосфера - экосистема - биота в прошлом Земли: палеобиогеографические аспекты. К 100-летию со дня рождения академика В. В. Меннера / отв. ред. Ю. Б. Гладенков, К. И. Кузнецова. Москва : Наука, 2005. С. 46-72.

Захаров В. Л., Шурысин Б. Н. Биогеография, фации и стратиграфия средней юры Советской Арктики (по двустворчатым моллюскам). Новосибирск : Наука, 1978. 206 c.

Захаров В. А., Курушин Н. И., Похиалайнен В. П. Палеобиогеографические критерии геодинамики террейнов Северо-Восточной Азии в мезозое // Геология и геофизика. 1996. Т. 37, № 11. С. 3-22.

Захаров В. А., Меледина С. В., Шурыгин Б. Н. Палеобиохории юрских бореальных бассейнов // Геология и геофизика. 2003. Т. 44, № 7. С. 664-675.

Зезина О. Н. Экология и распространение современных брахиопод. Москва : Наука, 1976. 139 с.

Зезина О. Н. Современные брахиоподы и проблемы батиальной зоны океана. Москва : Наука, 1985. 248 c.

Кальо Д. Л. Биогеография и климатическая зональность силура // Палеонтология, палеогеография и мобилизм : Труды 21-й сессии ВПО. Магадан : Кн. издво, 1981. С. 64-71.

Кафанов А. И. Двустворчатые моллюски и фаунистическая биогеография Северной Пацифики. Владивосток : ДВО АН СССР, 1991. 196 с.

Кафанов А. И. Историко-методологические аспекты общей и морской биогеографии. Владивосток : Изд-во Дальневост. ун-та, 2005. 208 с. 
Кафанов А. И., Огасавара К. Палеоген-неогеновые комплексы двустворчатых моллюсков Северной Пацифики // Вестник СВНЦ ДВО РАН. 2006. № 1. С. 49 60.

Князев В. Г., Прокопьев А. В. Биогеографическое районирование тоарских бореальных бассейнов // Отечественная геология. 1999. № 4. С. 33-34.

Крымгольи Г. Я., Эйнор О. Л. Вопросы биогеографии в Атласе литолого-палеогеографических карт СССР // Известия АН СССР. Сер. геол. 1972. № 1. C. $149-158$.

Курушин Н. И. Бореальная палеогеографическая область в триасовом периоде // Палеобиогеография, центры происхождения и миграция организмов : тез. докл. 41-й сессии Палеонтол. общества. Санкт-Петербург, 1995. С. 24-26.

Кусакин О. Г. Морские и солоноватоводные равноногие ракообразные (Isopoda) холодных и умеренных вод Северного полушария. Подотряд Flabellifera. Ленинград : Наука, 1979. 472 с.

Макридин В. П. Принципы выделения и номенклатура подразделений палеозоогеографического районирования морских бассейнов // Палеонтологический журнал. 1973. № 2. С. 3-9.

Макридин В. П., Мейен С. В. Палеобиогеографические исследования // Современная палеонтология. Методы, направления, проблемы, практическое приложение : справочное пособие: в 2-х т. / под ред. В. В. Меннера, В. П. Макридина. Москва : Недра, 1988. T. 2. C. 5-31.

Месежников М. С. О характере изменения границ палеозоогеографических областей и провинций // Палеобиогеография Севера Евразии в мезозое. Новосибирск : Наука, 1974. С. 77-87.

Миронов А. Н. Природа биотических границ // Общие вопросы морской биогеографии : Памяти академика О. Г. Кусакина / отв. ред. А. И. Кафанов. Владивосток : Дальнаука, 2004. С. 67-97. $312 \mathrm{c}$.

Морская биогеография. Москва : Наука, 1982.

Наймарк Е. Б., Марков А. В. Изменение провинциальности таксонов морских беспозвоночных в ходе эволюции // Биостратиграфия и эколого-биосферные аспекты палеонтологии : тез. докл. 44-й сессии Палеонтол. общества. Санкт-Петербург, 1998. С. 67-68.

Наймарк Е. Б., Марков А. В., Горюнова Р. В. Биогеография палеозойских мшанок : результаты количественного анализа // Палеонтологический журнал. 1999. № 3. C. 50-59.

Никитенко Б. Л. Палеобиогеография ранней юры и аалена Арктики по микробентосу (фораминиферы и остракоды) // Стратиграфия. Геологическая корреляция. 2008. Т. 16, № 1. С. 63-84.

Песенко Ю. А. Принципы и методы количественного анализа в фаунистических исследованиях. Москва : Наука, 1982. 288 с.

Попеко Л. И. Биогеография позднепермских мшанок юга Дальнего Востока // Тихоокеанская геология. 1996. Т. 15, № 4. С. 16-29.

Попов С. В. Зоогеография позднеэоценовых бассейнов Западной Евразии по двустворчатым моллюскам // Стратиграфия. Геол. корреляция. 1994. Т. 2, № 6. C. 103-118.
Сакс В. Н., Басов В. А., Дагис А. А., Дагис А. С., Захаров В. А., Иванова Е. Ф., Меледина С. В., Месежников М. С., Нальняева Т. И., Шульгина Н. И. Палеозоогеография морей Бореального пояса в юре и неокоме // Проблемы общей и региональной геологии. Новосибирск : Наука, 1971. С. 179-211.

Семенов В. Н. О биогеографическом показателе «степень эндемизма» // Океанология. 1975. Т. 15. Вып. 3. С. 526-527.

Сенников Н. В. Граптолиты палеозоя Средней Сибири (систематика, филогения, биохронология, биологическая природа, палеозоогеография). Новосибирск : Изд-во СО РАН, НИЦ ОИГГМ, 1996. $226 \mathrm{c}$.

Скарлато O. А. Двустворчатые моллюски умеренных широт западной части Тихого океана. Ленинград : Наука, 1981. 479 с.

Собецкий B. A. Некоторые вопросы палеобиогеографии и методики палеобиогеографического районирования // Вопросы палеобиогеографии. Уфа : Кн. изд-во, 1978. С. 17-25.

Старобогатов Я. И. Фауна моллюсков и зоогеографическое районирование континентальных водоемов земного шара. Ленинград : Наука, 1970. 372 с.

Талент Дж. Провинциализм и расхождение континентальных блоков в прошлом // Экостратиграфия, палеобиогеография и стратиграфические границы. Магадан : СВКНИИ ДВНЦ АН СССР, 1985. С. 5490.

Устрицкий В. И. Зоогеография позднепалеозойских морей Сибири и Арктики // Ученые записки НИИГА. Сер. палеонтол. и биостратигр. Ленинград : НИИГА, 1970. Вып. 29. С. 58-77.

Устрищкий В. И. О принципах выделения и номенклатуре крупнейших палеозоогеографических подразделений Земли // Палеонтологический журнал. 1986. № 3. С. 3-10.

Шульгина Н. И. Палеозоогеография морей Бореальной области в поздневолжское, берриасское и валанжинское время // Палеобиогеография Севера Евразии в мезозое. Новосибирск : Наука, 1974. С. 100 127.

Юферев О. В. Карбон Сибирского палеобиогеографического пояса. Новосибирск : Наука, 1973. $279 \mathrm{c}$.

Biakov A. S., Shi G. R. Palaeobiogeography and palaeogeographical implications of Permian marine bivalve faunas in Northeast Asia (Kolyma-Omolon and Verkhoyansk-Okhotsk regions, Northeastern Russia) // Palaeogeography, Palaeoclimatology, Palaeoecology. 2010. Vol. 298. Iss. 1-2. P. 42-53.

Cecca F., Westermann G. E. G. Towards a guide to palaeogeographic classification. 2003 // Palaeogeography, Palaeoclimatology, Palaeoecology. 2003. Vol. 201. P. 179-181.

Jaccard $P$. The distribution of the flora in the alpine zone // New Phytology. 1912. Vol. 11. P. 37-50.

Kauffman E. G. Cretaceous bivalvia // Atlas of palaeobiogeography / Ed. A. Hallam. Amsterdam : Elsevier, 1973. P. 353-383.

Preston F. W. The canonical distribution of commonness and rarity. Pt. 2 // Ecology. 1962. Vol. 43, No. 3. P. 410-432. 
Shen S. Z., Shi G. R., Archbold N. W. A Wuchiapingian (Late Permian) brachiopod fauna from an exotic block in the Indus-Tsangpo suture zone, Southern Tibet, and its palaeobiogeographical and tectonic implications // Palaeontology. 2003. Vol. 46. P. 2. P. 225-256.

Shi G. R. Multivariate data analysis in palaeoecology and palaeobiogeography - a review // Palaeogeography, Palaeoclimatology, Palaeoecology. 1993. Vol. 105. P. 199-234.
Shi G. R., Archbold N. W. A Quantitative palaeobiogeographical analysis on the distribution of Sterlitamakian - Aktastinian (Early Permian) Western Pacific brachiopod faunas // Historical Biology. 1996. Vol. 11. P. 101-123.

Westermann G. E. D. Biochore classification and nomenclature in palaeobiogeography : an attempt at order // Palaeogeography, Palaeoclimatology, Palaeoecology. 2000. Vol. 158. No. 1-2. P. 1-13.

Поступила в редакциюю 11.06.2021 2.

Поступила после доработки 05.08.2021 2.

\title{
ON BIOGEOGRAPHIC RECONSTRUCTIONS OF MARINE FAUNAS OF THE GEOLOGIC PAST
}

\begin{abstract}
A. S. Biakov ${ }^{1,2}$
${ }^{I}$ North-East Interdisciplinary Scientific Research Institute n. a. N. A. Shilo, FEB RAS, Magadan ${ }^{2}$ North-Eastern State University, Magadan

Some issues in biogeographic reconstructions of marine faunas of the geologic past are considered. The nature of biogeographic boundaries is discussed, and the criteria for identifying and the rank of established biochories, in particular, the applicability of various indices of biogeographic similarity, are considered. It is concluded that only the use of the entire complex of paleobiogeographic methods permits to reconstruct the features of the ancient organisms geographical differentiation most reliably. Such reconstructions should be carried out for the most fractional time intervals at the species level and based on the integration of data for all fauna groups.
\end{abstract}

Keywords: paleobiogeography, biochories, nature, rank and criteria for the determination of biochories.

\section{REFERENCES}

Amitrov, O. V., 1996. Paleogeography and Climatic Zonation of Early Oligocene Seas West of Eurasia Based on Gastropods, Paleonthological Journal. 30, 1, 1-10.

Basov, I. A., 1999. Biogeography of the North Pacific Planktonic Foraminifers in the Paleocene and Eocene, Stratigraphy and Geological Correlation. 7, 1, 79-91.

Biakov, A. S., 2010. Zonal Stratigraphy, Event Correlation, Paleobiogeography of the Permian in Northeast Asia (by Bivalves). Magadan, NEISRI FEB RAS [In Russian with English Summary].

Biakov, A. S., Shi, G. R., 2010. Palaeobiogeography and Palaeogeographical Implications of Permian Marine Bivalve Faunas in Northeast Asia (Kolyma-Omolon and Verkhoyansk-Okhotsk Regions, Northeastern Russia), Palaeogeography, Palaeoclimatology, Palaeoecology. 298, 1-2, 42-53.

Biakov, A. S., Vedernikov, I. L., Kolesov, E. V., 2006. Preliminary Results of Studying of Permian Deposits of Southern Part of the Omulevka Block (Northeastern Asia), Geology, Geography and Biologic Diversity of Northeastern Russia, Proceedings of the Far East Regional Conference Dedicated to the Memory of A. P. Vaskovsky and His 95 ${ }^{\text {th }}$ Birth Anniversary (Magadan, November 28-30,2006). Magadan, NESC FEB RAS. 71-75 [In Russian].
Bogoslovskaya, M. F., 1997. Biogeographic Analysis of the Middle and Late Carboniferous Ammonoids, Paleonthological Journal. 31, 5, 465-477.

Bragin, N. Yu., 2005. Paleobiogeographic Regionalization of Triassic Water Areas by Radiolarians, Biosphere - Ecosystem - Biota in the Past of the Earth: Paleobiogeographic Aspects. Moscow, Nauka. 157-177 [In Russian].

Cecca, F., Westermann, G.E.G., 2003. Towards a Guide to Palaeogeographic Classification, Palaeogeography, Palaeoclimatology, Palaeoecology. 201, 179-181.

Dagis, A. S., 1970. Triassic Brachiopods. Morphology, System, Phylogeny, Stratigraphic Significance and Biogeography. Avtoref. Dis. ... Doctora Geol.-Miner. Nauk. Novosibirsk [In Russian].

Gladenkov, Yu. B., 2005. Stratigraphy and Current Trends in Paleobiogeographic Research, Biosphere Ecosystem - Biota in the Past of the Earth: Paleobiogeographic Aspects. Moscow, Nauka. 17-45 [In Russian].

Goryunova, R. V., Naimark, E. B., Markov, A. V., 2004. Evolution and Biogeography of Paleozoic Bryozoans : Quantitative Analysis Results. Moscow, GEOS [In Russian].

Grunt, T. A., 1995. Biogeography of Permian Sea Basins, Paleonthological Journal. 29, 4, 10-24 [In Russian]. 
Grunt, T. A., Rozanov, A. Yu., 1995. Some Issues in Historical Biogeography, Paleobiogeography, Centers of Origin and Migration of Organisms. Abstracts, $41^{\text {nd }}$ Session of the Russian Paleonthological Society. 18-20 [In Russian].

Grunt, T. A., Rozanov, A. Yu., Alekseyeva, R. E., Manankov, I. N., 1994. Some Approaches to the Problems of the Historical Biogeography of Sea Basins, Ecosystem Restructuring and Evolution of the Biosphere. Moscow, PIN RAN. Iss. 1, 205-212 [In Russian].

Jaccard, P.,1912. The Distribution of the Flora in the Alpine Zone, New Phytology. 11, 37-50.

Kafanov, A. I., 1991. Bivalve Mollusks and Faunistic Biogeography of the North Pacific. Vladivostok, DVO AN USSR [In Russian].

Kafanov, A. I., 2005. Historical and Methodological Aspects of General and Marine Biogeography. Vladivostok, Far East University [In Russian].

Kafanov, A. I., Ogasavara, K., 2006. Paleogene-Neogene Assemblages of Bivalve Mollusks in the Northern Pacific, Vestnik NESC FEB RAS. 1, 49-60 [In Russian].

Kaljo, D. L., 1981. Biogeography and Climatic Zonation of the Silurian, Paleontology, Paleogeography and Mobilism : Proceedings of the $21^{\text {st }}$ Sesion of the Russian Paleonthological Society. Magadan. 64-71 [In Russian].

Kauffman, E. G., 1973. Cretaceous Bivalvia, Atlas of Palaeobiogeography, Ed. A. Hallam. Amsterdam, Elsevier. 353-383.

Knyazev, V. G., Prokopyev, A. V., 1999. Biogeographic Regionalization of the Toarcian Boreal Basins, Otechestvennaya Geologiya. 4, 33-34 [In Russian].

Krymgolts, G. Ya., Eynor, O. L., 1972. Issues in Biogeography in the Atlas of Lithological and Paleogeographic Maps of the USSR, Izvestiya AN USSR. Ser. Geol. 1, 149158 [In Russian].

Kurushin, N. I., 1995. Boreal Paleogeographic Realm in the Triassic Period, Paleobiogeography, Centers of Origin and Migration of Organisms. Abstracts of the $41^{\text {st }}$ Session of the Russian Paleonthological Society. SaintPetersburg. 24-26 [In Russian].

Kusakin, O. G., 1979. Marine and Brackish Water Isopods (Isopoda) of Cold and Temperate Waters in the Northern Hemisphere. Suborder Flabellifera. Leningrad, Nauka [In Russian].

Makridin, V. P., 1973. Principles of Identification and Nomenclature of Subdivisions of Sea Basin Paleozoogeographic Regionalization, Paleonthological Journal. 2, 3-9 [In Russian].

Makridin, V. P., Meyen, S. V., 1988. Paleobiogeographic Research, Modern Paleontology. Methods, Directions, Problems, Practical Applications : Reference Manual. In 2 Vol. Eds. V. V. Menner, V. P. Makridin. Moscow, Nedra. 2, 5-31 [In Russian]. sian].

Marine Biogeography, 1982. Moscow, Nauka [In Rus-

Mesezhnikov, M. S., 1974. On the Nature of Changes in the Boundaries of Paleozoogeographic Regions and Provinces, Paleobiogeography of North Eurasia in the Mesozoic. Novosibirsk, Nauka. 77-87 [In Russian].

Mironov, A. N., 2004. Nature of Biotic Boundaries, General Issues of Marine Biogeography : In Memory of Academician O. G. Kusakin. Vladivostok, Dalnauka. 6797 [In Russian].
Naymark, E. B., Markov, A. V.,1998. Changes in the Provinciality of Marine Invertebrate Taxa in the Course of Evolution, Biostratigraphy and Ecological-Biosphere Aspects of Paleontology. Abstracts of the $44^{\text {th }}$ Session of the Russian. Paleonthological. Society. Saint-Petersburg. 67-68 [In Russian].

Naymark, E. B., Markov, A. V., Goryunova, R. V., 1999. Biogeography of Paleozoic Bryozoans : Quantitative Analysis, Paleonthological Journal. 33, 3, 263-271 [In Russian]

Nikitenko, B. L., 2008. The Early Jurassic to Aalenian Paleobiogeography of the Arctic Realm : Implication of Microbenthos (Foraminifers and Ostracodes), Stratigraphy and Geological Correlation. 16, 1, 59-80.

Pesenko, Yu. A., 1982. Principles and Methods of the Quantitative Analysis in Faunistic Research. Moscow, Nauka [In Russian].

Popeko, L. I., 1996. Biogeography of Late Permian Bryozoans in the South of the Far East, Russian Journal of Pacific Geology. 15, 4, 16-29 [In Russian].

Popov, S. V., 1994. Zoogeography of the Late Eocene Basins of West Eurasia by Bivalve Mollusks, Stratigraphy and Geological Correlation. 2, 6, 103-118 [In Russian].

Preston, F. W., 1962. The Canonical Distribution of Commonness and Rarity. Pt. 2, Ecology. 43, 3, 410-432.

Saks, V. N., Basov, V. A., Dagis, A. A., Dagis, A. S., Zakharov, V. A., Ivanova, E. F., Meledina, S. V., Mesezhnikov, M. S., Nalnyaeva, T. I., Shulgina, N. I., 1971. Paleozoogeography of the Boreal Belt Seas in the Jurassic and Neocomian, Problems of General and Regional Geology. Novosibirsk, Nauka. 179-211 [In Russian].

Scarlato, O. A., 1981. Bivalve Mollusks from Temperate Latitudes of the Western Pacific Ocean. Leningrad, Nauka [In Russian].

Semyonov, V. N., 1975. On the Biogeographic Indicator "Degree of Endemism", Oceanology. 15, 3, 526-527 [In Russian].

Sennikov, N. V., 1996. Paleozoic Graptolites in Central Siberia (Taxonomy, Phylogeny, Biochronology, Biological Nature, Paleozoogeography). Novosibirsk, SB RAS, NITs OIGGM [In Russian].

Shen, S. Z., Shi, G. R., Archbold, N. W., 2003. A Wuchiapingian (Late Permian) Brachiopod Fauna From an Exotic Block in the Indus-Tsangpo Suture Zone, Southern Tibet, and Its Palaeobiogeographical and Tectonic Implications, Palaeonthology. 46, 2, 225-256.

Shi, G. R., 1993. Multivariate Data Analisis in Palaeoecology and Palaeobiogeography - a Review, Palaeogeography, Palaeoclimatology, Palaeoecology. 105, 199-234.

Shi, G. R., Archbold, N. W.,1996. A Quantitative Palaeobiogeographical Analysis on the Distribution of Sterlitamakian - Aktastinian (Early Permian) Western Pacific Brachiopod Faunas, Historical Biology. 11, 101123.

Sobetsky, V. A., 1978. Some Issues in Paleobiogeography and Methods of Paleobiogeographic Regionalization, Issues in Paleobiogeography. Ufa. 17-25 [In Russian].

Shulgina, N. I., 1974. Paleozoogeography of the Seas of the Boreal Region in the Late Volga, Berriassian, and Valanginian Times, Paleobiogeography of North Eurasia 
in the Mesozoic. Novosibirsk, Nauka. 100-127 [In Russian].

Starobogatov, Ya. I., 1970. Fauna of Mollusks and Zoogeographic Zonation of Continental Water Basins of the Globe. Leningrad, Nauka [In Russian].

Talent, J., 1985. Provincialism and the Divergence of Continental Blocks in the Past, Ecostratigraphy, Paleobiogeography, and Stratigraphic Boundaries. Magadan, SVKNII DVNTC AN USSR. 54-90 [In Russian].

Ustritsky, V. I., 1970. Zoogeography of the Late Paleozoic Seas of Siberia and the Arctic, Uchenyie Zapiski NI$I G A$, Ser. Paleontol. and Biostratigr. Leningrad, NIIGA. 29, 58-77 [In Russian].

Ustritsky, V. I., 1986. On the Distinguishing Principles and Nomenclature of the Earth's Largest Paleozoogeographic Subdivisions, Paleontological Journal. 3, 3-10 [In Russian].

Vilenkin, B. Ya., Shileyko, A. A., 1979. A Method for Assessing the Level of Fauna Endemism, Zoological Journal. 58, 11, 1720-1727 [In Russian].

Westermann, G. E. D., 2000. Biochore Classification and Nomenclature in Palaeobiogeography : an Attempt at Order, Palaeogeography, Palaeoclimatology, Palaeoecology. 158, 1-2, 1-13.

Yolkin, E. A., Talent, J. A., Gratsianova, R. T., 1985. Australian-Asian Late Silurian - Early Carboniferous Brachiopods and Trilobites, Russian Geology and Geophysics. 12, 3-7 [In Russian].

Yolkin, E. A., Talent, J. A., Izokh, N. G., Kipriyanova, T. P., Kipriyanov, A. A., Gratsianova, R. T., Yolkina, V. N., Shcherbanenko, T. A., 2007. Zonation of the Early-Middle Devonian Seas of Northern Eurasia Based on Quantitative Estimates of Paleobiogeographic Relationships between Regional Species Associations of Brachiopods,
Upper Paleozoic in Russia : Stratigraphy and Paleogeography. Materials of the All-Russia Scientific Conference. Kazan, Kazan State University. 102-107 [In Russian].

Yuferev, O. V., 1973. Carboniferous of the Siberian Paleobiogeographic Belt. Novosibirsk, Nauka [In Russian].

Zakharov, V. A., 2003. Comparative Analysis of Palinspastic and Paleobiogeographic Reconstructions of HighLatitude Regions in the Northern Hemisphere in the Mesozoic, Paleontology and Nature Management. Abstracts of the $49^{\text {th }}$ Session of the Russian Paleontological Society. Saint-Petersburg. 93-95 [In Russian].

Zakharov, V. A., 2005. Paleobiogeography, Paleogeography, and Paleogeodynamics, Biosphere - Ecosystem - Biota in the Past of the Earth : Paleobiogeographic Aspects. The $100^{\text {th }}$ Birth Anniversary of Academician V. V. Menner, Eds. Yu. B. Gladenkov, K. I. Kuznetsova. Moscow, Nauka. 46-72 [In Russian].

Zakharov, V. A., Kurushin, N. I., Pokhialainen, V. P., 1996. Paleobiogeographic Criteria for the Geodynamics of Northeast Asia Terranes in the Mesozoic, Russian Geology and Geophysics. 37, 11, 3-22 [In Russian].

Zakharov, V. A., Meledina, S. V., Shurygin, B. N., 2003. Paleobiochores of Jurassic Boreal Basins, Russian Geology and Geophysics. 44, 7, 633-644.

Zakharov, V. L., Shurygin, B. N., 1978. Biogeography, Facies, and Stratigraphy of the Middle Jurassic in the Soviet Arctic (by Bivalve Mollusks). Novosibirsk, Nauka [In Russian].

Zezina, O. N., 1976. Ecology and Distribution of Modern Brachiopods. Moscow, Nauka [In Russian].

Zezina, O. N., 1985. Modern Brachiopods and Problems of the Bathyal Zone of the Ocean. Moscow, Nauka [In Russian]. 